\title{
Why are you happy with impulse buying? Evidence from Indonesia
}

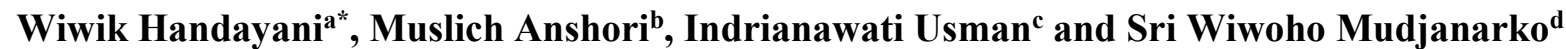

${ }^{a}$ Department of Management, Faculty of Business and Economic, Pembangunan Nasional “Veteran” East Java University, Indonesia ${ }^{b}$ Department of Management, Faculty of Business and Economic, Airlangga University, Indonesia

${ }^{c}$ Department of Management, Faculty of Business and Economic, Airlangga University, Indonesia ${ }^{d}$ Department of Civil Engineering, Faculty of, Civil Engineering, Narotama University, Indonesia

\section{CH R O N I C L E A B S T R A C T}

Article history:

Received: November 26, 2017

Received in revised format: January 31,2018

Accepted: March 16, 2018

Available online:

March 16, 2018

Keywords:

Experiential Marketing

Shopping Enjoyment

Impulse Buying

Happiness

\begin{abstract}
Happiness is an ideal condition needed by everyone. In the real life, happiness comes not only from the harmony in the home but also from the exciting environment or atmosphere outside the home, such as impulse buying. When someone makes impulse buying, she could feel the happiness because she gets something she wants. This means that when someone makes a purchase, she will experience happiness. This study aimed to examine the variables that affect impulse buying which may also affect the happiness. It is assumed that the experience and the pleasant shopping atmosphere affect the impulse buying and, as a result, the impulse buying affects happiness. The samples in this study were 150 women making purchases of fashion products at malls in Surabaya. The hypothesis testing was conducted by using Structural Equation Modelling. The test results indicated the hypothesis 1 stating that the experiential marketing influenced the impulse buying and hypothesis 2 stating that the shopping enjoyment affected the impulse buying were accepted. Further, hypothesis 3 were also accepted, stating that the impulse buying influenced happiness.
\end{abstract}

(C) 2018 by the authors; licensee Growing Science, Canada

\section{Introduction}

There is an interesting phenomenon in which a person feels happy when making the impulse buying, whereas many researchers state that the impulse buying is a purchase that is emotionally made. There is a contrast condition, considering that, in general, a person will feel happy when shopping according to plans or, in other words, the cognitive elements play the role. Another phenomenon is that many women tend to linger in malls. This is illustrated by the increasing the number of women whose hobby is visiting malls. In a week they could go to malls from three to four times and always make a purchase (Muruganantham \& Bhakat, 2013). There are times when a woman does not think about the benefits of the goods purchased because they merely want to experience the incredible pleasure while shopping and fulfilling their needs (http://www.yuswohady.com). Thus, she becomes irrational due to the emotional act. Today, many women work outside the home and have high mobility. The higher the mobility, the higher the stress level. To diminish the stress, these career women entertain themselves by going shopping or window-shopping to malls. As a consequence, this recreational activity is often followed

\footnotetext{
* Corresponding author.

E-mail address: wiwik.em@upnjatim.ac.id, sri.wiwoho@narotama.ac.id (W. Handayani) 
by unplanned purchases that could make them happy and dispose of the stresses. This is supported by the findings of online research MarkPlus Insight in mid-2010 on 1,301 female respondents in eight major cities in Indonesia. It showed that women's favorite activities to do with friends were shopping (46.4 percent) and hanging out (46.1 percent), whereas the prime location chosen was malls. In fact, 39.7 percent of women stated that their favorite activity was sightseeing to the mall with their family. The survey showed how the urban upper-middle class women spent the weekend, for the same reason, refreshing and disposing of stresses. Another phenomenon is the tendency of career women to visit and linger at malls. Besides window shopping, women have the tendency to have the pleasure of buying shoes, bags, or clothing. This is also supported by a number of malls built in one complex with office premises, thereby completing the facilities that women need to spend their leisure time during the lunch hour. They assume that visiting the malls on the weekend is an activity to recharge energy, so the next day they go to work in fresh condition. In the beginning, most women go to the malls merely for window-shopping. However, many are affected by sales or discounts. Women's expansive character makes them compare prices, models, brands, and qualities, but the result is the same. The purchased goods are goods that are affordable. Thus, shopping is their way of finding the pleasure and happiness.

Happiness is a trending topic in psychology and economics study and has been applied to marketing and human resources (Alba \& Williams, 2013). Happiness is studied by measuring both the emotive and cognitive happiness. Therefore, we need to understand the meaning of happiness in accordance with the classification. Happiness can be defined into two groups: the hedonistic tradition and the eudemonic tradition (Deci \& Ryan, 2008). The hedonistic tradition focuses on the happiness that is generally defined as the presence of both positive and negative influences. Meanwhile, the eudemonic tradition is defined as focusing on life by getting full and in-depth satisfaction. Therefore, it can be said that happiness in hedonistic tradition can be obtained in such short time or the moment's pleasure, such as shopping, eating out, recreation and so forth. Meanwhile, in the eudemonic tradition, happiness is obtained through a long process, based on experiences that reflect the joy of life. This condition can be exemplified from the research stating that for people with a western cultural background, happiness usually comes from personal success, personal expression, self-esteem, and high self-appreciation. On the contrary, in Asian countries, happiness comes from fulfilling the expectations of family and society, from the fulfillment of social obligations, self-discipline, and cooperation of friendship (http://my-musings.blogdrive.com/archive/30.html). But it turns out that in the 21 st century, almost everyone in the world seeks happiness in accordance with self-emotional fulfillment or, in other words, has already imitated the western style. For instance, people will feel happy if they could spend time lingering at the malls, shopping for things that may not be necessary, hunting for branded goods, and looking for new goods in order to be different from everyone else. Based on the existing phenomena, the researchers focused the study on happiness based on the hedonic tradition. Hedonic tradition shows the way of obtaining happiness through some emotional ways, without thinking and considering that being happy and having fun are the most important things. This behavior leads people to make impulse buying when they are in the shopping places (Ismail \& Mokhtar, 2015).

Someone will feel happy when she gets what she wants. This can occur with or without any plans. In general, if a person gets what she has planned and felt happy, that is an ordinary thing. However, if someone does something that has never been planned before and she felt happy, that is unusual or peculiar. In reality, there are many things occurring unplanned but they give happiness. For example, a woman walks into a mall without any specific purpose and plans. It happens accidentally because of a friend's invitation or as a time-filler or disposing of stresses. While walking around the counters at the mall, she suddenly sees an interesting product and spontaneously buys it. As a result, she feels very happy and relieved. Whereas, the decision to make a purchase was not based on any plans. This is called an impulse buying. 
Impulse buying (Stern, 1962) is a purchase made without any prior plans or may occur spontaneously. Impulse buying is a purchase made without planning and spontaneity. Research result finds that Impulse buying is the purchase made without any intention to buy a certain product, category, or brand. The research further shows that the majority of buyers are planners $(59.9 \%)$, followed by partial planners $(27.7 \%)$, and the impulse buyers $(12.3 \%)$. The results of this study explain that impulse buying is also one kind of a buying decision.

Impulse buying could give a sense of happiness to the people. A person can feel happy after making the impulse buying. In other words, the feelings that occur after making a purchase impulsively are happiness, pleasure, excitement, and joy (Gardner, 1988). This could happen because the decision is emotionally made with low control. In brief, the decision is made emotionally, instead of cognitively. The emotional decisions are mostly done by women. Fashion products purchased by women were made impulsively which means that many women make the purchases have a low control ability (Vohs \& Faber, 2007). Almost 59\% of women and 48\% men prefer impulse buying. This suggests that women are more likely to do impulse buying than men. The products that are purchased by women are clothed, cosmetics, accessories, jewelry, trending products, and products that can determine their social status (Kong-Hee, 2012; Mitchell \& Walsh, 2004). Impulse buying does not only result in happiness by providing a sense of comfort, satisfaction, and pleasure but also results in regret. Saleh (2012) states in his research that impulse buying leads to regret (Saleh, 2012). In contrast, Gardner, et al. (1998) states that a person who enjoys impulse buying may experience a good feeling, fun, and even happiness. The difference may happen because when the impulse buying is based on negative emotions are bad mood, the effect would be regretted, anxiety, and mistake. On the other hand, if it is based on positive emotions, the door will feel happy (Gardner, 1988; Saleh, 2012; Broz et al., 2018)

Impulsive behavior can also be triggered by the company marketing strategy (experiential marketing) and the shopping enjoyment. The company marketing strategy through experiential marketing will provide experience for the customers which is called experiential customers. Additionally, impulse buying is highly influenced by how customers enjoy purchasing activity (Herabadi, 2003). Stimuli created by marketers are targeted to make the buyers feel happy. They enjoy the pleasant conditions during a visit to the mall or shopping centers. This pleasant condition makes consumers comfortable and lingers and look for products. People go shopping not only because they need to buy things, but also because they can really enjoy shopping. This condition is called shopping enjoyment.

In the shopping activities, besides functional and practical aspects, shopping can be fun, relaxing, or interesting (Ismail El-Adly, 2007). The emotional consumption experience is closely related to the shopping enjoyment, namely the pleasure of getting something in the shopping process, which is conceptualized as an individual difference variable (Beatty \& Ferrell, 1998; Muruganantham \& Bhakat, 2013). This means that someone when making a purchase will experience various kinds of pleasure. In the process, impulsive buying emphasizes the emotional aspects of the consumption experience and the purchase is highly influenced by emotions. Positive emotions will trigger happiness and lead people to enjoy the shopping process. The shopping enjoyment can greatly lead to impulse buying. The shopping enjoyment has a positive impact on impulse buying (Herabadi, 2003).

Impulse buying based on a positive mood will provide a feeling of happiness (Gardner, 1988). On the other hand, if it is based on negative mood, it would cause regret (Saleh, 2012). Happiness is a general perspective of satisfaction. When people feel that the goods purchased are in accordance with the desire, there is a sense of satisfaction or happiness. The research mentioned above show a relationship or association between impulse buying and happiness. In general, it can be said that happiness can occur as a result of impulse buying (Alba \& Williams, 2013; Sekar \& Uthayakumar, 2018). Until recently, there are many research on happiness associated with gender, age, education, ethnicity (Diener, 2000), and brand (Bettingen \& Luedicke, 2009) social factors and the buying experience (Nicolao et al., 2009). In this study, happiness was influenced by impulsive buying behavior, experiential marketing, and 
shopping enjoyment. The importance of research on happiness in a retail shopping is to understand consumer behavior after making impulsive buying that will affect other customers to behave the same. Therefore, it will have a positive effect on increasing sales. Additionally, it will provide marketers, knowledge of marketing strategies in the retail sector in the future.

\section{Literature Review}

\subsection{Experiential Marketing on Impulse Buying}

Experiential marketing is a strategy created by marketers to generate stimuli for consumers and provide a pleasant experience for a product or the environment where the product is located. According to Schmitt (2010), experiences are personal events that occur due to certain stimuli (e.g. The effort given by the marketers before and after the purchase of goods or services). This explains that an experience is important because it will provide a stimulus to the consumer both before and after making a purchase in order to always be remembered. The experience can be gained through sense, feel, think, act, and relate. This is in line with Schmitt (2010) who states that experiential marketing is a strategy used to create the buyer's or consumer's experience.

Sense is the consumer experience creation through the five senses. Eyes are used to see the beauty of the product; ears are used to listen to the music in order to make people remember; nose is used to smell a refreshing fragrance, and tongue and skin are used to feel comfort or tranquility. Feeling is the creation of experience through the moods and emotion by good service and the employee's hospitality. Most consumers will be regular customers once they feel comfortable with the product or service being offered. In addition, the consumers' good mood experienced through the products and services will result in a memorable experience. The good feeling will make customers think positively. Meanwhile, thinking is a suggestion to consumers to play an active role in solving problems together with manufacturers, aiming to influence customers to engage in creative thinking. For example, when a customer enters the store, $\mathrm{s} /$ he is faced with the choice of products or services. Then, the customer is expected to combine his/her own choice and enjoy the combination of his/her choices of products and services that s/he purchases. Furthermore, acting is the act of giving the consumer experiences in conjunction with the physical form of the product or service that is perceived as well as affecting customer's habits, lifestyle, and interaction with others. For example, when buying clothes at the mall, customers can try it out first. It will provide an experience for the consumer. In addition, relating is linking individuals with the surroundings and implementing the relationships with other individuals and other social groups so that they can feel proud of being accepted in the community. For example, relating is built by the manufacturer to its customers, by making direct contact via telephone and physical contact, to make them a member so that consumers would be happy and do not hesitate to return.

Marketers can create experiences through the environment and products including colors, smells, sounds, textures, and locations. It can also be created through the store environment (e.g. Layout, interior architecture and decoration, lighting, music that evokes quality, aroma, and cleanliness). The environment can affect the consumers' emotional state and show a higher level of impulse buying behavior (Mattila \& Wirtz, 2001). The experience built by the manufacturers will affect the emotional aspect or stimulate consumers to better remember the products, the shop, or visited places before and after making a purchase. Emotions are a major source of human motivation and provide a major influence on the process of memory and thinking (Brosch et al., 2013). The emotional aspects of the consumption experience, because of the emotional nature of buying behavior, seem to be dominant in the impulsive buying.

Meanwhile, Experiential marketing is a concept that combines elements of emotions, logic, and overall thinking process and then connects them to the consumers (Gibson et al., 2010). The goal is to build a relationship in which consumers respond to products offered in accordance with the emotion and the 
level of their thinking. Experiential Marketing shows how to create a product by offering not only functional benefits but also emotional benefits through experience enjoyed by fellow visitors.

It is also an attempt to create an enjoyable experience for consumers so that they will choose the product. By considering the wide variety of the senses, experiential marketing is looking for a special place in consumers' mind to attract their attention and influence their thinking in relation to comfort and joy they desire.

The experience provides the knowledge to marketers to gain market share and influence their target consumers' mindset. The experience formed through experiential marketing will stimulate someone to make a buying decision (Schmitt, B. (2011). Using the sense, feel, think, act, and relate will affect consumer's emotional decision-making, thereby increasing the tendency to make impulse buying. Experiential value affects the impulse buying and the impulse buying is influenced by the display carried out by the retailer (Chang et al., 2016).

\subsection{The Effect of Shopping Enjoyment on Impulse Buying}

People go shopping not only because they need to buy things, but also because they can really enjoy going shopping. Enjoy shopping influences impulse buying. Indeed, besides the functional and practical aspects, shopping can be fun, relaxing, or interesting (Ismail El-Adly, 2007)

The consumption experience is explained through the category of emotional experience and expression (e.g. Joy, anger, fear) or with underlying structural dimensions of emotional categories, such as discomfort enjoyment, relaxation action, excitement, or calmness. The emotional reaction in two main dimensions, pleasure, and arousal (i.e. A subjective experience of hedonic tone and activation, respectively) (Alba \& Williams, 2013; Farrag et al, 2010). Emotions consumption can be distinguished from the affective phenomena related to moods (Kong-Hee, 2012; Gardner, M. P. (1985) on the basis of the urgency of psychological emotion that is relatively larger, the potential for motivation, and situational specificity. Therefore, it is clear that an emotional consumption experience is closely associated with the shopping enjoyment, getting pleasure in the shopping process. It is then clarified by Beatty and Ferrell (1998); Muruganantham and Bhakat (2013) that an emotional experience is closely related to the shopping enjoyment in which the pleasure in the shopping process is conceptualized as a variety of individual differences.

Recreational buyers (e.g. Individuals who enjoy shopping) has been known to spend more time shopping and lingering after making a purchase. The number of stores leads to more excitement that trigger the desire to stay longer in the mall and, therefore, increases search activity (Beatty \& Ferrell, 1998). Encouragement of buying tendency relates to the shopping enjoyment. The higher the shopping enjoyment, the higher the impulse buying tendency (Herabadi, 2003). The hedonic value of recreational orientation is caused by the enjoyment and the pleasure, instead of completing tasks (Ismail El-Adly, 2007). Recreational buyers are known to spend more time shopping and take long in making purchasing decisions. This happens because recreational buyers enjoy shopping with a lot of fun. A pleasant shopping atmosphere will provide satisfaction for leisure buyers. The satisfaction obtained from the shopping process is greater than the goods purchased. When shopping, buyers make choices based on a wide selection of products or prices, however, they go shopping without planning what to buy and ultimately adopt an impulsive buying plan as they shop. The enjoyment of shopping provides an opportunity and influences one to buy impulsively. From the opinions, it can be concluded that the shopping enjoyment makes people linger longer in the stores or malls that trigger someone to do impulse buying. 


\subsection{The Effect of Impulse Buying on Happiness}

In the hedonistic tradition, the focus on happiness is generally defined as the presence of both positive and negative influences. Waterman and colleagues define hedonist well as a positive feeling of getting the desired object or having the opportunity to fulfill their desires. More emphasis is placed on the products their definition. Happiness in the hedonic tradition, therefore, can be obtained in a moment of pleasure, such as shopping, eating, recreation and so on. A hedonist or subjective view is intended to demonstrate that basically the act of wellbeing consists of subjective perception of both happiness and pleasure experiences (Diener, 2000). In psychological terms, hedonic well-being, can be expected to be perceived whenever pleasurable affection accompanies the needs, both physically, intellectually, or socially based on (Muruganantham \& Bhakat, 2013). Materialistic and narcissistic thinking is associated with a post-purchase mood that involves high passion (e.g. Excitement), and situational thinking may be associated with post-mood buying involving relatively low passions (e.g. Pleasure). Happiness is a number of material pleasures and considers life to maximize pleasure or pleasure (Bettingen \& Luedicke, 2009). There are many indications of impulse purchases make feelings of being good, happy, satisfied. This opinion explains the influence of impulse buying with happiness (Nicolao et al., 2009). Many people experience a positive mood after an impulse purchase (due to product satisfaction, cooling impulse, etc.) (Gardner, 1988). People who experience a fluctuating mood, i.e. those who tend to experience a negative mood after impulse buying usually feel that they made a mistake or rather a feeling of regret (Saleh, 2012). Materialism and narcissistic thinking is related to the mood and the situational post-purchase mind. Post-purchase moods involve high passion (e.g. Excitement). Situational postpurchase minds involve relatively low passions (e.g. Pleasure). Happiness depends on frequency positive impact, or joy, high levels of satisfaction over a period of time (Bettingen \& Luedicke, 2009).

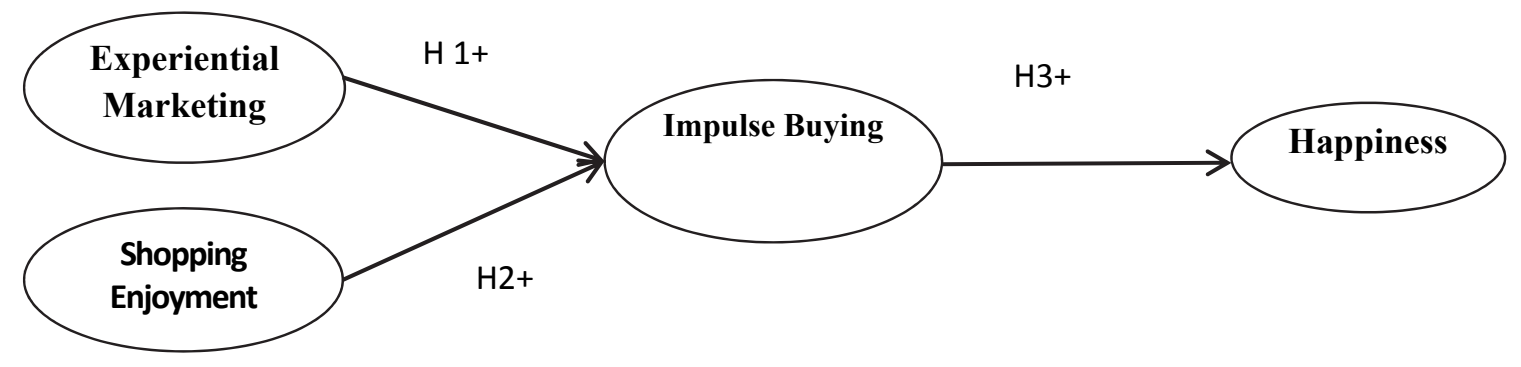

Fig. 1. Conceptual Model

Shopping is a leisure time activity or a function of a motive of not purchasing things because it only necessitated for social interaction, entertainment, a diversion from routine activities, or sensory stimulation (Farrag et al., 2010). This is in order to get more satisfaction from the shopping process than from the goods purchased, especially in impulse buying. On the other hand, the convenience emphasizes the useful value of shopping as something associated with the tasks, sensibility, cautiousness, and the efficiency of the activities (Babin et al., 1994).

The conceptual model of this research can be seen in Fig. 1. Furthermore, it is hypothesized: H1. Experiential marketing has an effect on impulse buying; H2: Shopping enjoyment has an effect on impulse buying; H3: Impulse Buying has an effect on happiness.

\section{Methodology}

The population in this study was female visitors of the fashion department at the malls in Surabaya. The respondents were taken purposive with the following criteria: woman, age above 17 years, and shopping at the department store. 
Experiential marketing is the experience of the product obtained through consumers' emotional and rational, involving all the senses in order to motivate consumers through the experience. This variable is formed by five dimensions (sense, feel, think, act, and relate). There were seventeen indicators measured. Shopping enjoyment is an emotional experience associated with the enjoyment of shopping during the shopping process. There were eight indicators measured. Impulse buying is the unplanned purchase with the characteristic that the decision is quickly made, and there is a desire to own the things quickly. There were six indicators as a measure. Happiness is a positive feeling that is characterized by the pleasure felt by an individual when doing something s/he likes in his/her life with no sense of suffering. There were six indicators measured.

\section{Results and Finding}

The validity test result of the values of correcting item-total correlation for all indicators in this study is valid. The reliability test is used to determine whether the answers given by the respondents were trustworthy or reliable. All variables in this study, which are experiential marketing (sense, feel, think, act, and relate), shopping enjoyment, impulse buying, and happiness have a Cronbach Alpha value higher than r-table (0.60), meaning that all variables in this study are reliable. Based on the analysis of the construct reliability of the Experiential Marketing dimensions, the results are a sense of 0.618 , feel of 0.720 , think of 0.610 , the act of 0.660 , relate of 0.620 , meaning that all data are reliable and can be used for further analysis. Furthermore, on the Experiential Marketing variables, the construct reliability is 0.765; Shopping enjoyment is 0.774; Impulse Buying is 0.682; and Happiness 0.817, meaning that the variables in this study are reliable and can be used for further analysis. After conducting multidimensional testing on each construct using Confirmatory Factor Analysis, the next step is analyzing the Structural Equation Modeling (SEM) with a theory-based full model. To test the suitability of the model that had been modified, the criteria of Goodness of Fit were applied as follows:

Table 1

The Evaluation of Criteria of Goodness of Fit Indices Model One-Step Approach - Modification

\begin{tabular}{llll}
\hline Criteria & Cut-off Value & $\begin{array}{l}\text { Computed } \\
\text { sult }\end{array}$ & re- \\
\hline Chi-Square & expected small & 642.571 & Good \\
Significance Probability & $\geq 0,05$ & 0.161 & Good \\
RMSEA & $\leq 0,08$ & 0.020 & Good \\
GFI & $\geq 0,90$ & 0.822 & Fair \\
AGFI & $\geq 0,90$ & 0.794 & Fair \\
CMIN/DF & $\leq 2,00$ & 2.724 & Fair \\
TLI & $\geq 0,95$ & 0.967 & Good \\
CFI & $\geq 0,95$ & 0.970 & Good \\
\hline
\end{tabular}

The modifications of structural model result in a reduction of the value of $\chi^{2}$ to be 642.571 with probability equal to 0.161 . This value is greater than $5 \%$ so that the variance-covariance matrix of the population is equal to the variance-covariance matrix of the estimated models. Besides the probability value, it can be seen that all criteria already met the specified cut off value limit. After the appropriate model was obtained, the significance of the model can be seen by comparing the value of the probability of any causal relationship with $\alpha(5 \%)$. The loading and significance values are presented in Table 2 below: 
Table 2

Loading Factor of Full Model Modification Structural Equation Modeling

\begin{tabular}{lllll}
\hline & $\begin{array}{c}\text { Ustd } \\
\text { mate }\end{array}$ & $\begin{array}{c}\text { Esti- } \\
\text { STD Estimate }\end{array}$ & C.R. & P \\
\hline $\begin{array}{l}\text { Experiential marketing to impulse buy- } \\
\text { ing }\end{array}$ & 0.401 & 2.175 & 2.961 & 0.003 \\
Shopping enjoyment to impulse buying & 0.442 & 0.438 & 3.003 & 0.003 \\
Impulse buying to happiness & 0.647 & 0.645 & 4.219 & 0.000 \\
\hline
\end{tabular}

Experiential marketing has a significant positive effect on impulse buying, judging from STD estimate value of 2.175 with a $\mathrm{p}$-value of 0.003 ( $\mathrm{sic}<5 \%$ ). When the purpose of the shopping experience is for pleasure or emotional satisfaction, the product purchased is seen as the selected one without any plans and it presents an event of impulse buying. From the results of the research, the objective of experiential marketing is to build a relation which consumers respond to products offered in accordance with emotion and their thinking level. Taking into account the wide variety of a person's senses, experiential marketing is looking for a special place in the minds of consumers to attract their attention that is done by influencing their thinking about the comfort and joy of what the consumers' desired. In other words, the marketer must strive to get and influence target consumers' mindset. Shopping enjoyment has a significant positive effect on impulse buying, seen from STD estimate value of 0,438 with a p-value of 0.003 ( sic $<5 \%$ ). People go shopping not only because they need what they buy, but also because they can really enjoy shopping. Enjoying shopping influences the impulse buying (Nishanov \& Ahunjonov, 2016). Indeed, instead of the functional and practical aspects, shopping can be fun, relaxing, or interesting (Beatty \& Ferrell, 1998). Recreation buyers (e.g. Individuals who enjoy shopping) has been known to spend more time shopping and lingering after making a purchase. The number of stores leads to more excitement that trigger the desire to stay longer in the mall and, therefore, increases search activity (Beatty \& Ferrell, 1998). Encouragement of buying tendency relates to the shopping enjoyment. The higher the shopping enjoyment, the higher the impulse buying tendency (Herabadi, 2003).

The hedonic value of recreational orientation is caused by the enjoyment and the pleasure of playing, instead of completing tasks (Ismail El-Adly, 2007). From the aforementioned opinions, it can be concluded that the shopping enjoyment makes people linger longer in the stores or malls that trigger the impulse buying. Shopping is a leisure time activity or a function of a motive not to purchase things since it is only a need for social interaction, entertainment, a diversion from routine activities, or sensory stimulation (Farrag et al., 2010). This is in order to get more satisfaction from the shopping process than from the goods purchased, especially shopping without any prior plans (impulse buying). On the other hand, the convenience emphasizes the useful value of shopping as something associated with the tasks, sensibility, cautiousness, and the efficiency of the activities (Babin et al., 1994).

Impulse buying has a significant positive effect on happiness seen from STD estimate value of 0.645 with a p-value of $0.000(\mathrm{sic}<5 \%)$. There were many indications of impulse buying that made people feel good, happy, satisfied, roaming, beautiful, or high. This opinion explains the influence of impulse buying on happiness. A lot of people experience a positive mood after impulse buying (due to product satisfaction, motive fulfillment, etc.) (Gardner, 1988). Bettingen and Luedicke (2009), explain that happiness is material enjoyment and a notion that life is maximizing pleasure or enjoyment (Bettingen \& Luedicke, 2009). However, it should be understood that a person's mood is fluctuating. Sometimes people experience a positive mood or a negative one after making impulse buying. If a negative mood occurs after making impulse buying, there will be feelings of guilt or regret (Saleh, 2012). The materialistic and narcissistic mind might be associated with moods after the purchasing, thereby involving high arousal (e.g. Joy), and the situational mind may be associated with moods after the purchasing involving relatively low arousal (e.g. Pleasure). 


\section{Conclusion}

The result of this study shows that impulse buyer does not always result in regret, but has also produce happiness. This is shown by the results of the analysis that is significantly positive that impulse buying affected happiness. This study rejects the result of the previous studies which stated that impulse buying tend to lead to customers' regret. This study result also provides knowledge to marketers or companies that there are factors require serious attention in determining the programs related to the marketing of products in order to be attractive and create a feeling of happiness. Feel marketing is an effort of the marketer or company to tie the emotions of consumers through small concerns to form a fun mood and emotions for consumers to be the same or as expected marketers to create happiness. A pleasant experience formed by sense, feel, think, act and relate experienced by consumers will encourage consumers to make impulse buying. Impulse buying based on positive experiences will result in consumers' happiness. Impulse buying can also be caused by a pleasant shopping condition. Shopping enjoyment can occur because of a sense of excitement when doing shopping, feeling relaxed, and feeling doing a recreational activity that leads to happiness.

The future research consumers' decision making may differ between one consumer and another, so the results of the decision also vary. Such differences may be caused by several factors. Based on the observations and evaluation conducted in this study, one of the influential factors is personality because it also plays a role in a person's buying decision. It could be associated with emotional and cognitive factors. These factors may act as variables that affect, strengthen, or weaken the relation between impulse buying and happiness, which means that the possibilities in making buying decisions can be strengthened or weakened by the nature or character of the consumers. For those reasons, a person's character can be considered as a moderating variable in future studies. An emotional state of a person, especially a woman has a tendency to change or less stable becomes vulnerable to changes in decision making. This becomes an opportunity for further research that long-term observation is necessary to be able to understand the emotional stability of a person associated with impulse buying. Furthermore, cognitive factors require in-depth assessment to provide an explanation of someone who always thinks realistically or uses cognitive whether to make impulse buying or not. Facility or technology cause one to think easily making it possible to choose to make purchase easy or simple. Purchase without having to use any preparations or plans. This means that technological progress becomes a variable that needs to be considered in the assessment of impulse buying. The existence of some variables or factors that become limitations in this study and allows give effect to impulse buying variable, hence indicate that there are still many opportunities in subsequent research. Environment changes more and more factors or variable provide and opportunity for subsequent research.

\section{References}

Alba, J. W., \& Williams, E. F. (2013). Pleasure principles: A review of research on hedonic consumption. Journal of Consumer Psychology, 23(1), 2-18.

Babin, B. J., Darden, W. R., \& Griffin, M. (1994). Work and/or fun: measuring hedonic and utilitarian shopping value. Journal of Consumer Research, 20(4), 644-656.

Beatty, S. E., \& Ferrell, M. E. (1998). Impulse buying: Modeling its precursors. Journal of Retailing, 74(2), 169-191.

Bettingen, J. F., \& Luedicke, M. K. (2009). Can brands make us happy? A research framework for the study of brands and their effects on happiness. ACR North American Advances, 36, 308-315.

Brosch, T., Scherer, K. R., Grandjean, D. M., \& Sander, D. (2013). The impact of emotion on perception, attention, memory, and decision-making. Swiss Medical Weekly, 143, w13786.

Broz, D., Rossit, D., Rossit, D., \& Cavallín, A. (2018). The Argentinian forest sector: opportunities and challenges in supply chain management. Uncertain Supply Chain Management, 6(4), 375-392.

Chang, S. W., Loukides, G., \& Ahmed, S. (2016). Assessing the drivers of online impulse buying. 4th 
Int Conf Contemp Mark Issues. 2016:1-5.

Deci, E. L., \& Ryan, R. M. (2008). Hedonia, eudaimonia, and well-being: An introduction. Journal of Happiness Studies, 9(1), 1-11.

Diener, E. (2000). Subjective well-being: The science of happiness and a proposal for a national index. American Psychologist, 55(1), 34.

Farrag, D. A., El Sayed, I. M., \& Belk, R. W. (2010). Mall shopping motives and activities: a multimethod approach. Journal of International Consumer Marketing, 22(2), 95-115.

Gardner, M. P. (1985). Mood states and consumer behavior: A critical review. Journal of Consumer research, 12(3), 281-300.

Gardner, M.P. (1988). Effects of impulse purchases on consumers affective states. Advanced Consumer Resources, 15, 127-130.

Gibson, D. G., Glass, J. I., Lartigue, C., Noskov, V. N., Chuang, R. Y., Algire, M. A., ... \& Merryman, C. (2010). Creation of a bacterial cell controlled by a chemically synthesized genome. Science, $329(5987), 52-56$.

Herabadi, A. G. (2003). Buying impulses: A study on impulsive consumption.

Ismail El-Adly, M. (2007). Shopping malls attractiveness: a segmentation approach. International Journal of Retail \& Distribution Management, 35(11), 936-950.

Ismail, S. \& Mokhtar, S. (2015). Moderating effect of perceived risk on the relationship between product safety and intention. Management Science Letters, 5(2), 205-212.

Kong-Hee, K. (2012). Emotion and strategic decision-making behavior: Developing a theoretical model. International Journal of Business and Social Science, 3(1), 105-113.

Muruganantham, G., \& Bhakat, R. S. (2013). A review of impulse buying behavior. International Journal of Marketing Studies, 5(3), 149.

Mitchell, V. W., \& Walsh, G. (2004). Gender differences in German consumer decision-making styles. Journal of Consumer Behaviour, 3(4), 331-346.

Mattila, A. S., \& Wirtz, J. (2001). Congruency of scent and music as a driver of in-store evaluations and behavior. Journal of Retailing, 77(2), 273-289.

Nishanov, B., \& Ahunjonov, U. (2016). The Influence Of Store Characteristics On Consumers' Impulse Buying Behaviour. Journal of International Business Research and Marketing, 1(3), 20-26.

Nicolao, L., Irwin, J. R., \& Goodman, J. K. (2009). Happiness for sale: do experiential purchases make consumers happier than material purchases?. Journal of Consumer Research, 36(2), 188-198.

Schmitt, B. (2011). Experience marketing: concepts, frameworks and consumer insights. Foundations and Trends ${ }^{\circledR}$ in Marketing, 5(2), 55-112.

Sekar, T \& Uthayakumar, R. (2018). A production inventory model for single vendor single buyer integrated demand with multiple production setups and rework. Uncertain Supply Chain Management, 6(1), 75-90.

Saleh, M. A. E. H. (2012). An investigation of the relationship between unplanned buying and postpurchase regret. International Journal of Marketing Studies, 4(4), 106.

Shah, S. H. A., Gul, S., Shakir, H., \& Qureshi, I. (2013). Switching cost and consumer behaviour: A structural analysis of telecom sector of Pakistan. World Applied Sciences Journal, 28(4), 513-527.

Stern, H. (1962). The signficance of buying impulse Today. Journal of Maketing, 26(2), 59-62.

Vohs, K. D., \& Faber, R. J. (2007). Spent resources: Self-regulatory resource availability affects impulse buying. Journal of Consumer Research, 33(4), 537-547.

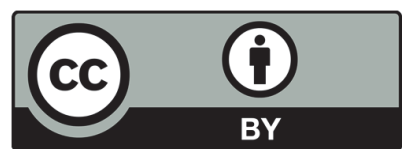

(C) 2018 by the authors; licensee Growing Science, Canada. This is an open access article distributed under the terms and conditions of the Creative Commons Attribution (CC-BY) license (http://creativecommons.org/licenses/by/4.0/). 